\title{
SUKSES MENGEMBANGKAN DESAIN \\ SENI DAN KERAJINAN MENJAHIT APLIKASI \\ BERBAHAN DASAR LIMBAH KAIN (KAIN PERCA) \\ BAGI INDUSTRI RUMAH TANGGA
}

\author{
Titi Indahyani \\ Jurusan Desain Interior, Fakultas Komunikasi Multimedia, Bina Nusantara University \\ Jln. K.H. Syahdan No.9, Palmerah, Jakarta Barat 11480 \\ tindahyani@binus.edu
}

\begin{abstract}
Arts and craft products are now beginning to be produced by many home industries such as sewing patchwork application products. But the lack of knowledge of art, design and product marketing in this industry making products become less competitive and provide income earning less than the maximum. Besides, home industry players sometimes do not have the high endurance and sustainability in business. As one of the national strategic issues, the arts, crafts and creative industries get serious attention from the government. It is expected with the opening horizons of knowledge in art, design and product marketing in the area of sew patchwork application craft (which is use the waste fabric) will impact the development of entrepreneurship opportunities and support many home industries entrepreneur from local micro become sustainable macro business. This action will also support to further explore the various culture of Indonesian arts, crafts and other creative industries became more creative, innovative and competitive by using waste materials that are environmentally friendly.
\end{abstract}

Keywords: entrepreneurship, home industri, art and craft design development, recycled product, business chance

\begin{abstract}
ABSTRAK
Produk seni dan kerajinan saat ini sudah marak diproduksi oleh kalangan industri rumah tangga, seperti produk menjahit aplikasi kain perca. Namun minimnya pengetahuan seni, desain, dan pemasaran produk di kalangan industri ini membuat produk menjadi kurang kompetitif serta terkadang pelaku industri tidak memiliki daya tahan dan keberlanjutan (sustainability) usaha yang tinggi. Sebagai salah satu isu strategis nasional, bidang seni, kerajinan dan industri kreatif mendapat perhatian yang cukup serius dari pemerintah. Diharapkan dengan terbukanya wawasan pengetahuan seni, desain dan pemasaran produk di bidang seperti menjahit aplikasi kain perca, yang sebagian besar berbahan dasar produk daur ulang akan berdampak berkembangnya peluang berwirausaha yang kelak akan mendukung industri rumah tangga yang bersifat mikro menjadi industri kreatif tingkat makro yang berkelanjutan serta memiliki daya tahan tinggi di bidangnya. Adanya hal ini membuat pelaku industri rumah tangga dapat lebih menggali kekayaan budaya Indonesia menjadi suatu hasil produk seni, kerajinan maupun industri kreatif lainnya menjadi lebih kreatif, inovatif, kompetitif dengan menggunakan bahan baku limbah industri yang ramah lingkungan.
\end{abstract}

Kata kunci: entrepreneurship, industri rumah tangga, pengembangan desain seni dan kerajinan, produk daur ulang, peluang bisnis 


\section{PENDAHULUAN}

Berdasarkan data dari Kementrian UKM, belakangan ini pertumbuhan bisnis Usaha Kecil dan Menengah (UKM) termasuk industri rumah tangga, menunjukkan gejala peningkatan. Bidang seni dan kerajinanpun turut menunjukkan peningkatan baik di sektor produksi maupun pelaku industrinya (pengrajin). Hal ini ditunjukkan pula dengan perhatian pemerintah yang cukup serius dalam mendukung pemberdayaan dan pengembangan UKM dengan produk tersebut di atas. Beberapa sentra UKM dibentuk dan didirikan pemerintah di pusat bisnis antara lain: pusat UKM di sekitar Bundaran HI dan di Gedung SMESCO di seputaran Pancoran. Pemerintah pun selalu mempromosikan produk UKM dengan memberi bantuan untuk mengadakan workshop, pameran serta temu muka dengan para pengusaha calon mitra usaha baik di dalam maupun di luar negeri.

Prospek yang cerah dari bisnis UKM di bidang seni dan kerajinan ini menimbulkan persaingan yang sangat ketat baik dari segi pemasaran, pengembangan usaha serta kualitas hasil produk walaupun pasar dalam negeri dan luar negeri masih terbuka luas. Menggiurkannya bisnis ini turut menarik minat banyak kalangan industri rumah tangga untuk turut mengambil peluang ini. Namun yang cukup disayangkan, masih banyak pebisnis UKM khususnya pelaku industri rumah tangga yang umumnya terdiri dari kalangan ibu rumah tangga dan menggeluti seni menjahit aplikasi kain perca, masih belum memiliki ketrampilan mengeskplorasi seni yang memadai guna menghasilkan produk yang kreatif, inovatif dan kompetitif. Pada umumnya banyak yang masih mengandalkan rancangan desain maupun pola yang berasal dari bentuk-bentuk yang sudah ada seperti meniru atau hanya sedikit melakukan modifikasi serta membuat produk hanya berdasarkan desain sesuai pesanan dari pelanggan saja. Bahkan masih banyak pula yang menerapkan cara coba dan salah (trial \& error) sehingga proses pengembangan desain menjadi terhambat baik dari segi waktu dan biaya.

Seyogyanya dengan dikembangkannya industri rumah tangga di bidang menjahit aplikasi kain perca ini secara tidak langsung akan meningkatkan kualitas pemberdayaan wanita yang dapat merupakan salah satu solusi bagi penyediaan lapangan kerja baik bagi masyarakat di daerah perkotaan maupun masyarakat pedesaan dan daerah pesisir. Masyarakat didaerah tersebut khususnya daerah wisata maupun yang berpotensi sebagai daerah wisata, umumnya memerlukan berbagai bentuk produk seni dan kerajinan yang kreatif yang dapat dijadikan sebagai tanda mata bagi wisatawan yang berkunjung ke daerah tersebut. Di samping itu terbukanya pengetahuan dasar tentang seni dan desain bagi produk menjahit aplikasi khususnya bagi masyarakat kurang mampu dan masyarakat daerah pesisir dapat menjadikan produk menjahit aplikasi ini menjadi lebih dapat diterapkan ke berbagai jenis produk seni dan kerajinan bahkan menjadi bagian dari aksesoris (penunjang dan pelengkap) interior. Dengan demikian diharapkan akan timbul berbagai macam penerapan produk menjahit aplikasi kain perca yang lebih kreatif dan mampu menghadapi persaingan yang ketat serta mampu berkembang menjadi lebih besar karena para pelaku industri ini telah memiliki pondasi yang memadai untuk menghasilkan produk yang unik dan dapat diaplikasikan ke beragam produk kebutuhan sehari-hari lainnya baik untuk lingkungan rumah tangga maupun kantor.

\section{METODE PENELITIAN}

Penulisan artikel ini menggunakan pendekatan observasi / pengamatan dan survei. Artikel ini juga berdasarkan data dan prosiding dari Kementrian UKM dan studi literatur. Semua sumber informasi diseleksi, dievaluasi dan dijadikan pendukung artikel. 


\section{PEMBAHASAN}

\section{Seni Menjahit Aplikasi sebagai bagian dari Industri Rumah Tangga}

Industri rumah tangga sebagai bagian dari UKM turut memberi andil adanya peluang berwirausaha bagi masyarakat. Industri rumah tangga dianggap pemerintah mampu untuk memaksimalkan pemberdayaan di kalangan masyarakat terutama kalangan remaja, wanita maupun masyarakat tidak mampu. Seni menjahit aplikasi tiga tahun belakangan ini cukup marak diminati remaja dan kalangan ibu rumah tangga baik sebagai hobi maupun sebagai bagian dari industri rumah tangga. Relatif mudahnya ketrampilan ini dipelajari, rendahnya biaya produksi dan pasar yang terbuka luas membuat banyak wirausahawan di industri rumah tangga ini menerbitkan buku serta membuka workshop ketrampilan menjahit aplikasi kain perca. Salah satu tujuan dibukanya workshop adalah untuk bermitra dengan banyak peserta workshop yang dianggap memiliki bakat ketrampilan menjahit aplikasi yang berkualitas Dengan demikian apabila industri rumah tangga ini dikembangkan secara maksimal dan berkelanjutan maka akan tercipta cukup banyak lapangan pekerjaan yang dapat merupakan salah satu solusi bagi isu nasional di bidang seni, kerajinan dan industri kreatif.

Berbagai macam industri rumah tangga yang ada dan sukses dijalankan tidak terlepas dari ketrampilan, bakat, talenta dan pengalaman yang dimiliki oleh pelaku industri tersebut. Produk makanan dan pakaian adalah beberapa produk yang banyak dihasilkan dari industri rumah tangga ini karena banyak yang beranggapan bahwa produk ini dapat dihasilkan oleh hampir semua orang. Namun tidak demikian halnya dengan produk seni dan kerajinan. Produk seni dan kerajinan memiliki keunikan khusus karena dianggap hanya orang tertentu yang memiliki ketrampilan khusus dengan pengalaman cukup panjang saja yang mampu menjalankan usaha ini secara berkelanjutan. Seni dan kerajinan sebagai salah satu alternatif industri rumah tangga saat ini mendapat perhatian yang cukup besar dari Pemerintah. Berbagai aktivitas untuk mendorong berkembangnya bidang ini sudah cukup sering dilakukan oleh berbagai pihak. Namun umumnya aktivitas tersebut lebih mengedepankan proses produksi saja tanpa adanya informasi menyeluruh tentang proses desain sampai dengan proses pemasaran produk hingga berhasil mendapatkan profit sesuai target yang direncanakan guna membangun usaha yang berkelanjutan.

\section{Seni Menjahit Aplikasi Kain Perca}

Aplikasi kain perca adalah suatu metode menempelkan dan menjahit sulam tangan sepotong kain perca diatas alas bidang kain lainnya. Metode ini menjadi suatu seni tersendiri karena aplikasi kain perca berarti pula merangkai potongan-potongan kain tersebut menjadi suatu bentuk gambar. Alas bidang lainnya tersebut dapat berupa kaos, kemeja, selimut, taplak dan lain-lain. Aplikasi dapat dijahit menggunakan mesin dan tangan. Namun pada artikel ini pembahasan aplikasi menggunakan jahit tangan dengan teknik sederhana antara lain tusuk tikam jejak putus, tusuk feston, tusuk rantai dan tusuk tangkai. Teknik sulam dengan tangan ini yang banyak dilakukan di industri rumah tangga karena tidak memerlukan modal yang besar untuk memulai suatu usaha. Hasil jahitan ini akan membuat aplikasi menjadi suatu desain yang unik, karena bentuk jahitan akan sangat jelas terlihat sebagai teknik yang menyatukan sepotong kain di atas kain lainnya. Beberapa contoh gambar di artikel ini mengambil pola aplikasi dengan jahit mesin untuk lebih memperkaya bentuk desain yang ditampilkan.

Umumnya seni menjahit aplikasi menggunakan bahan limbah industri dan produk tekstil yang berupa sisa potongan kain atau biasa disebut kain perca. Walaupun terlihat sebagai barang yang tidak berharga, limbah kain perca dapat diubah menjadi barang-barang yang berguna dan bernilai ekonomis mengingat kain perca memiliki corak dan tekstur yang beragam dan dapat dipadukan menjadi kreasi yang berguna termasuk sebagai unsur pelengkap interior rumah, seperti tirai, pengikat tirai (tassel), sarung bantal, sprei, selimut, kap lampu, tempat majalah, alas piring, alas gelas, tempat tissue, tempat pakaian kotor, kantong gantung serba guna dan lain-lain. 


\section{Proses Desain}

Ada beberapa proses penting yang umumnya perlu diketahui dan dipahami oleh para pengrajin dan wirausahawan industri rumah tangga khususnya di bidang seni dan kerajinan menjahit aplikasi sebagai upaya membangun usaha yang lebih kreatif, inovatif , kompetitif serta membangun usaha yang berkelanjutan. Salah satu proses desain yang penting adalah tahap pengembangan desain. Proses pengembangan desain diawali dengan adanya inspirasi desain yang dapat diilhami dari alam dan lingkungan di sekitar kita, gambar karakter kartun, dongeng, aktivitas manusia, fasilitas lingkungan, peralatan, transportasi, huruf, nama, dan lain-lain.

Proses selanjutnya adalah proses pengembangan inspirasi/ide desain menjadi ide-ide yang lebih jelas, tajam dan terarah yang akan membantu terbentuknya rencana desain yang nyata. Proses pengembangan ide desain menjadi suatu desain dapat dibantu dengan cara berpikir yang kreatif. Beberapa cara berpikir kreatif sederhana yang umumnya sering dipakai, antara lain: menyederhanakan, merubah, meniru, menjadikan baru, mencari kegunaan baru dan merubah arah. Terkadang bertukar pikiran dalam suatu kelompok akan sangat bermanfaat pula untuk mendapatkan maupun mengembangkan ide yang kreatif, baru dan segar. Bahkan cara memperbaiki sesuatupun akan dapat dijadikan beragam ide baru.

Beberapa contoh desain dibawah ini merupakan hasil pengembangan ide yang sudah melalui proses berpikir kreatif antara lain meniru, merubah dan menyederhanakan bentuk.

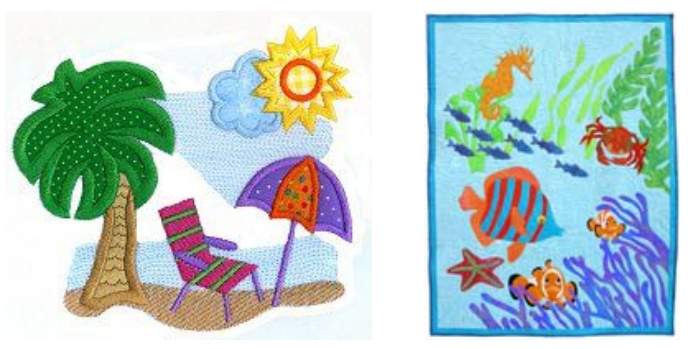

Gambar 1 Inspirasi dari Alam

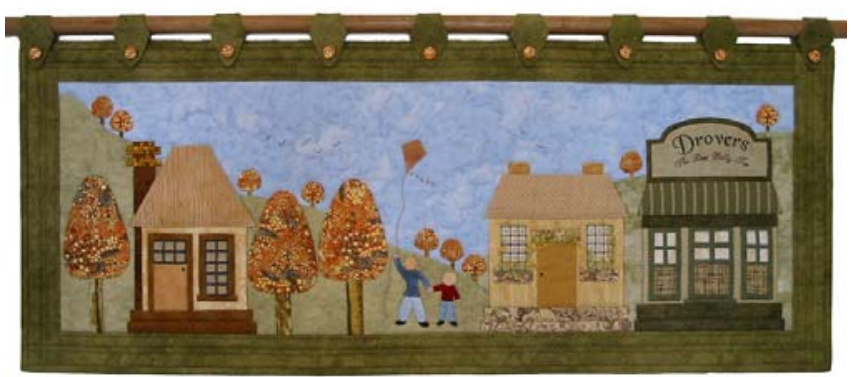

Gambar 2 Inspirasi dari Lingkungan Sekitar
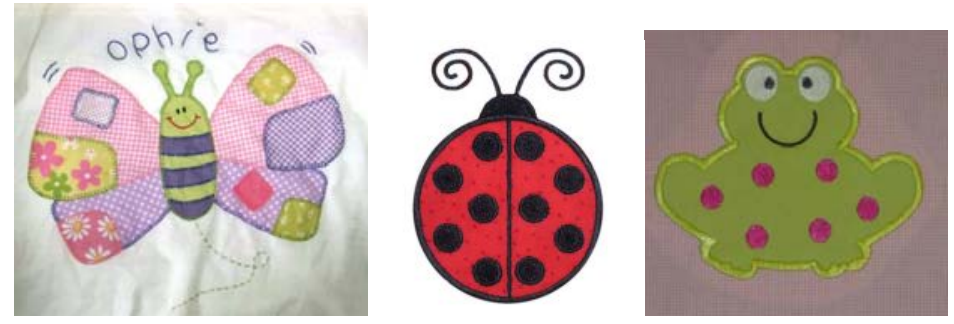

Gambar 3 Inspirasi dari Binatang 


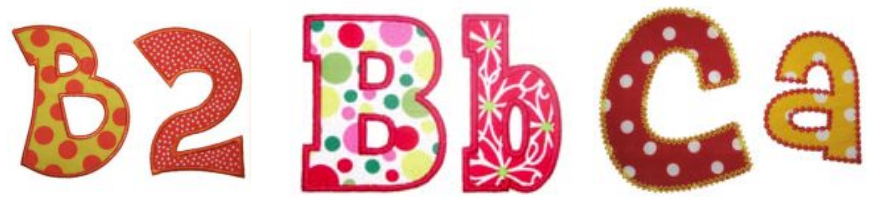

Gambar 4 Inspirasi dari Huruf dan Angka

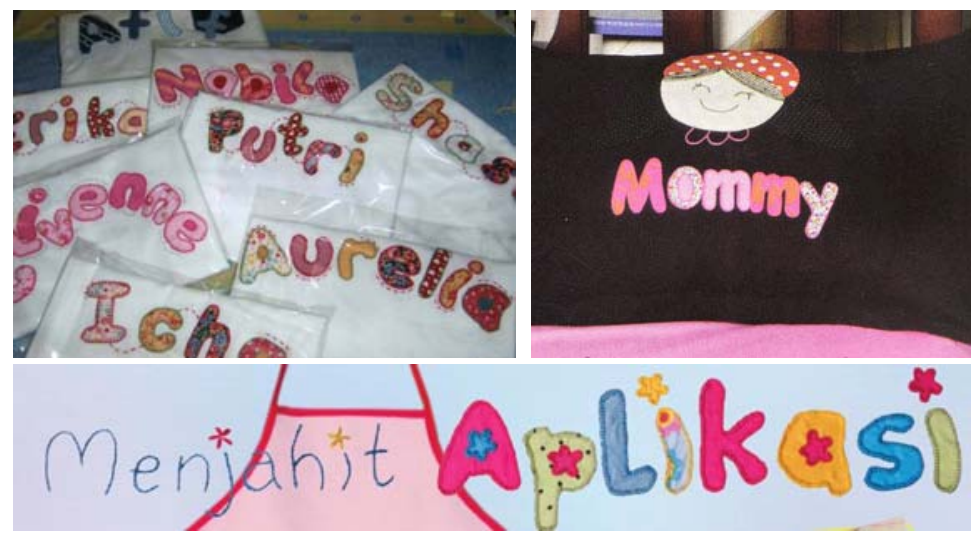

Gambar 5 Inspirasi dari Nama dan Rangkaian Kata
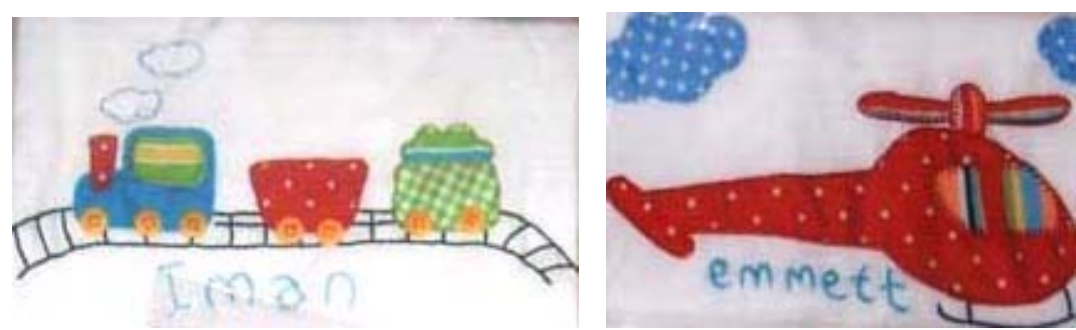

Gambar 6 Inspirasi dari Alat Transportasi
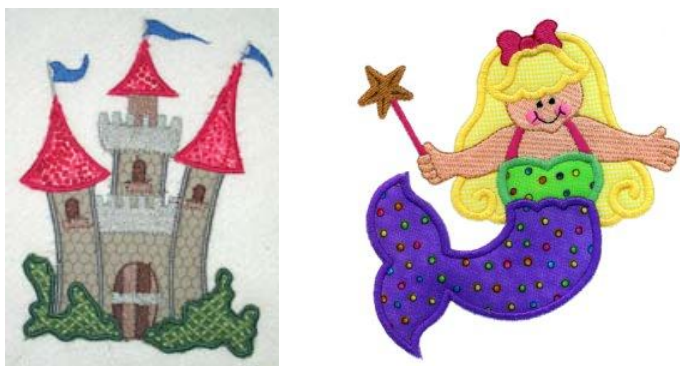

Gambar 7 Inspirasi dari Dongeng dan Kartun Anak
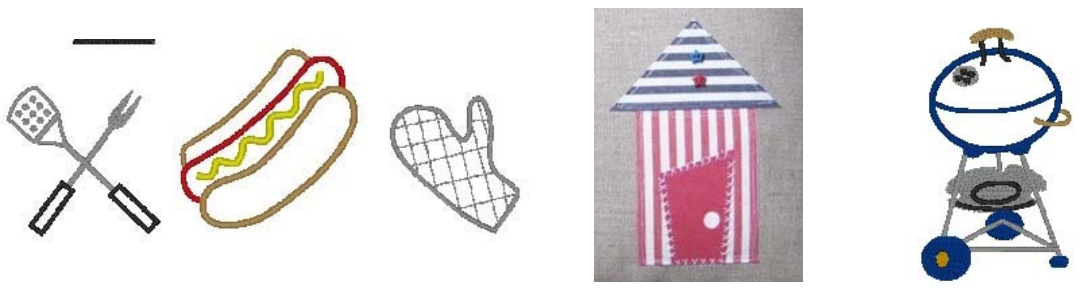

Gambar 8 Inspirasi dari Rumah, Fasilitas dan Peralatannya 

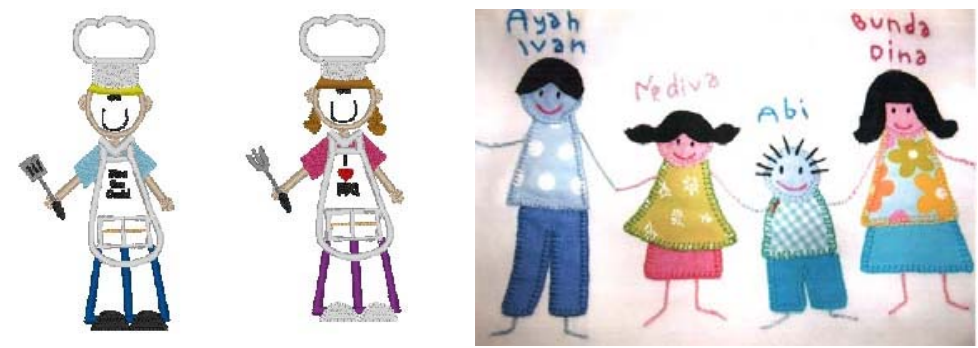

Gambar 9 Inspirasi Aktivitas Manusia

\section{Komposisi Desain}

Dalam proses mewujudkan ide menjadi suatu desain nyata yang terlihat indah dan menarik diperlukan paduan komposisi yang harmonis dan serasi antara bentuk, proporsi, ukuran, warna, motif, material dan tekstur. Dalam membuat komposisi desain diperlukan bentuk-bentuk dasar yang akan dipadukan dengan bentuk lain. Bentuk yang kita kenal umumnya dapat dibedakan menjadi bentuk yang beraturan dan tidak beraturan. Bentuk yang beraturan adalah bentuk-bentuk seperti segitiga, lingkaran, elips, segi empat, segi 6 maupun bentuk persegi lainnya.
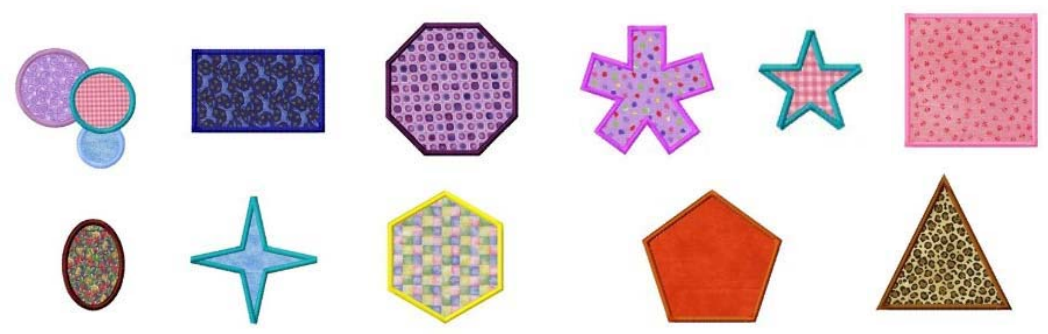

Gambar 10 Bentuk Beraturan (geometris)

Sedangkan bentuk yang tidak beraturan umumnya adalah bentuk-bentuk yang terdapat di alam, seperti bentuk dari bagian tubuh manusia, hewan dan tanaman.
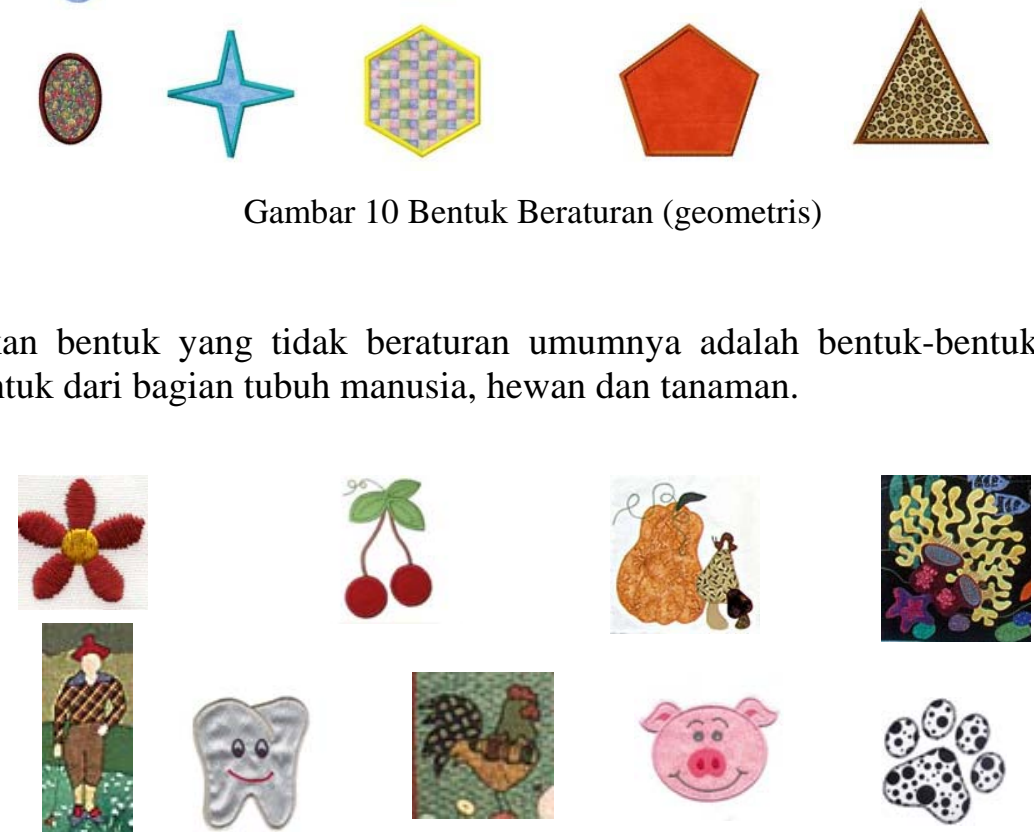
bentuk tubuh manusia merupakan proporsi yang baik. Sesuatu akan dikatakan "out of proportion" bila terlihat adanya ketidakseimbangan antar bentuk, misalnya saja, seseorang yang kepalanya lebih besar dibandingkan dengan bagian tubuh secara keseluruhan.

Sebagai tahap lanjutan dari pengembangan inspirasi, bentuk-bentuk dasar tersebut di atas dapat dikomposisikan dengan cara disusun berulang, dibuat menjadi ada kemiripan, dan dikombinasikan dengan beberapa bentuk, motif serta warna lainnya.

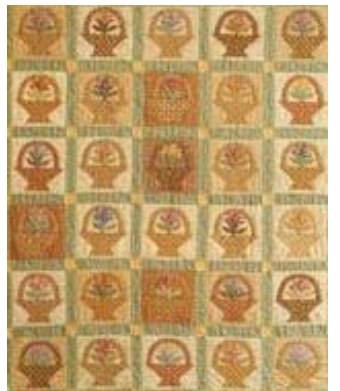

(a)

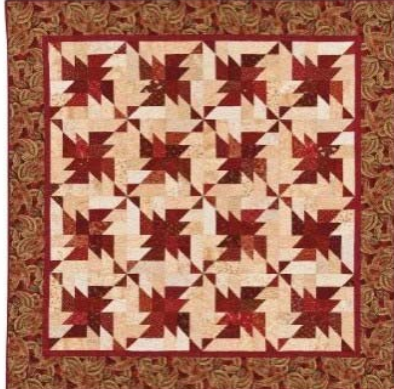

(b)

Gambar 12 (a) Penerapan Pola Kemiripan (b) Penerapan Pola Perulangan

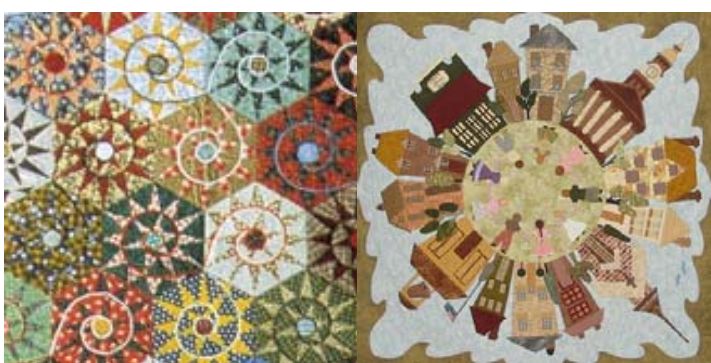

(a)

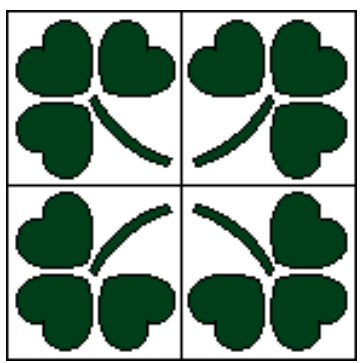

(b)

Gambar 13 (a) Penerapan Pola Radian dan Memusat; (b) Penerapan Pola Refleksi

Dalam menjahit aplikasi, komposisi pemilihan motif, warna, material dan tekstur turut berperan penting pula menjadikan desain terlihat harmonis disamping komposisi bentuk yang telah diuraikan sebelumnya.
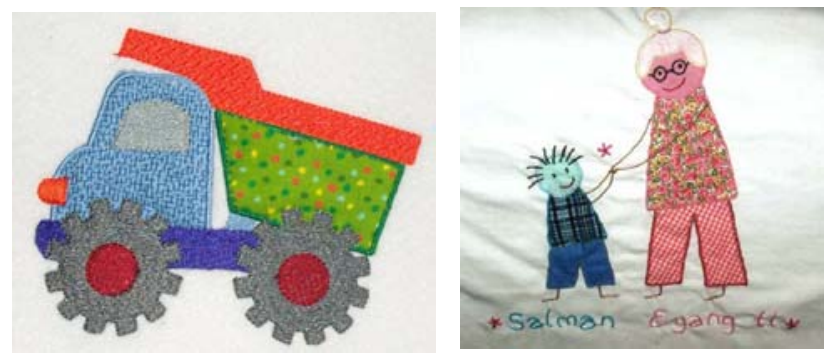

Gambar 14 Motif dalam Kain Perca Bermotif

Pada gambar desain aplikasi di atas, dipilih paduan kain perca bermotif kecil sehingga terlihat proporsional saat diaplikasikan pada bentuk desain. Kain bertekstur yang diaplikasikan pada roda dan rambut juga membuat desain aplikasi ini menjadi lebih bersifat tiga dimensi. Pada beberapa desain 
khusus bahkan ada bagian desain aplikasi yang dapat diangkat atau dibuka, misalnya bagian baju. Sehingga desain aplikasi menjadi lebih interaktif, unik dan menarik perhatian.

Pemilihan kombinasi dari kain perca yang akan digunakan dapat menjadi hal yang cukup menyulitkan mengingat keterbatasan akan jenis, warna dan motif kain perca yang dimiliki. Umumnya para pengrajin menjalin kerjasama dengan penjahit pakaian sehingga kain perca yang didapat menjadi lebih bervariasi. Namun hal ini hanya sesuai dilakukan bila desain aplikasi diproduksi dalam jumlah kecil. Akan lain halnya bila pesanan datang dalam jumlah besar maka diperlukan kombinasi kain perca dengan jumlah yang cukup banyak untuk tiap jenis dan motif kain karena satu pola desain bisa diproduksi sekaligus dalam jumlah banyak dengan motif dan warna yang sama. Untuk menyiasatinya dapat memakai barang tak terpakai dari pakaian, taplak, sprei dan lain-lain dengan jenis kain dan motif yang serupa atau hampir sama.

Paduan warna yang harmonis patut menjadi pertimbangan pertama saat memilih kain perca. Ada kalanya suatu desain aplikasi yang unik akan terlihat kurang menarik karena tidak menggunakan kombinasi warna yang tepat. Ada beberapa jenis kombinasi warna dasar yang dapat dijadikan panduan saat menentukan kombinasi warna, antara lain kombinasi warna primary, secondary, tertiary, analogus, split complementsary, rectangle (tetradic), square color scheme. Warna primary adalah warna merah, biru dan kuning. Campuran antara dua warna primer akan menghasilkan warna secondary sedangkan campuran satu warna primer dengan warna secondary akan menghasilkan warna tertiary. Kombinasi dan campuran warna ini dapat dengan mudah dilihat melalui skema roda warna (Color Wheels), seperti pada Gambar 15.

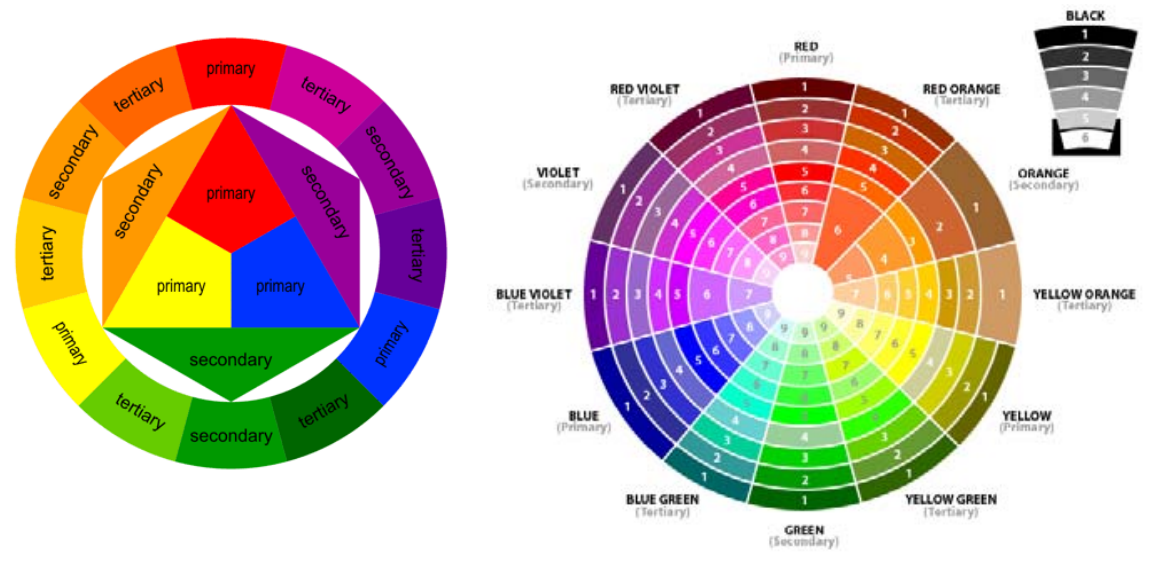

Gambar 15 Skema roda warna (colour wheels)

Di bawah ini adalah contoh hasil karya seni menjahit aplikasi dengan menggunakan kombinasi warna-warna tersebut diatas.
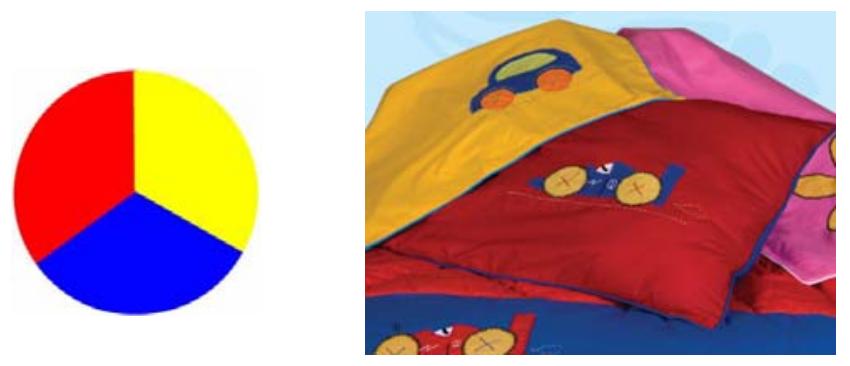

Gambar 16 Penerapan Primary Color pada Bed Cover, Sprei, Sarung Bantal dan Guling 

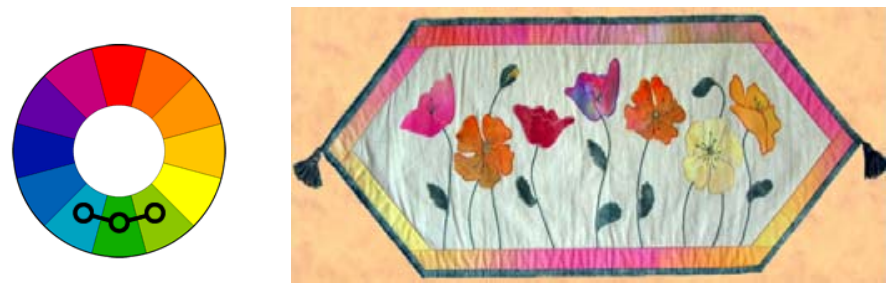

Gambar 17 Penerapan Analogous Color pada Taplak Meja Berukuran Panjang (Runner)
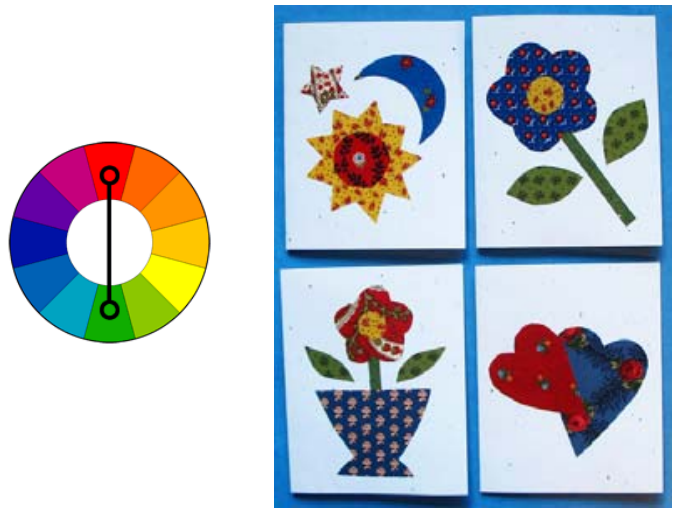

Gambar 18 Penerapan Complementary Color pada Wall Hanging
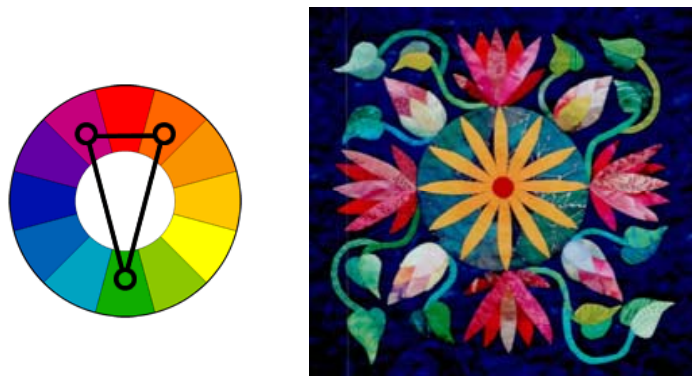

Gambar 19 Penerapan Split Complementary Color pada Wall Hanging
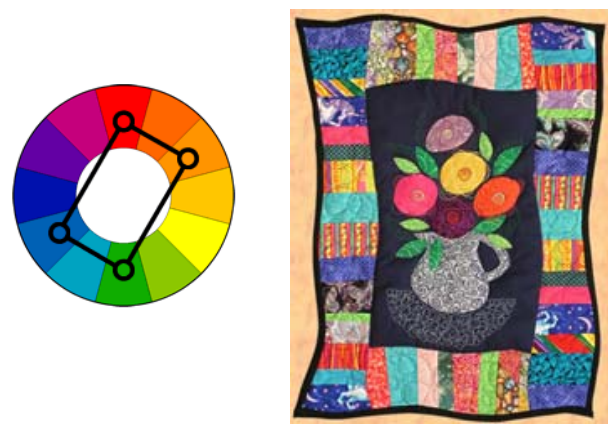

Gambar 20 Penerapan Tetradic Color pada Bed Cover 

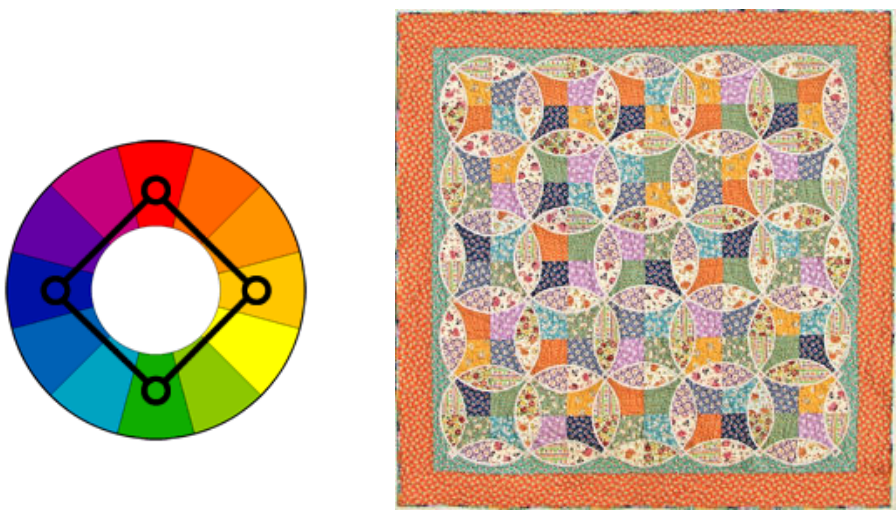

Gambar 21 Penerapan Tetradic Color pada Bed Cover

Warna juga terbagi atas warna hangat dan dingin. Pada roda warna di atas, warna hangat adalah merah, oranye dan kuning sedangkan warna dingin adalah hijau, biru dan ungu. Disamping kombinasi warna tersebut di atas, dikenal juga suatu penerapan konsep warna yang sederhana. Warna dapat dibuat dengan konsep semakin terang dengan menambahkan putih (tints), dibuat semakin gelap dengan menambahkan warna hitam (shade) atau warna abu-abu (tone).
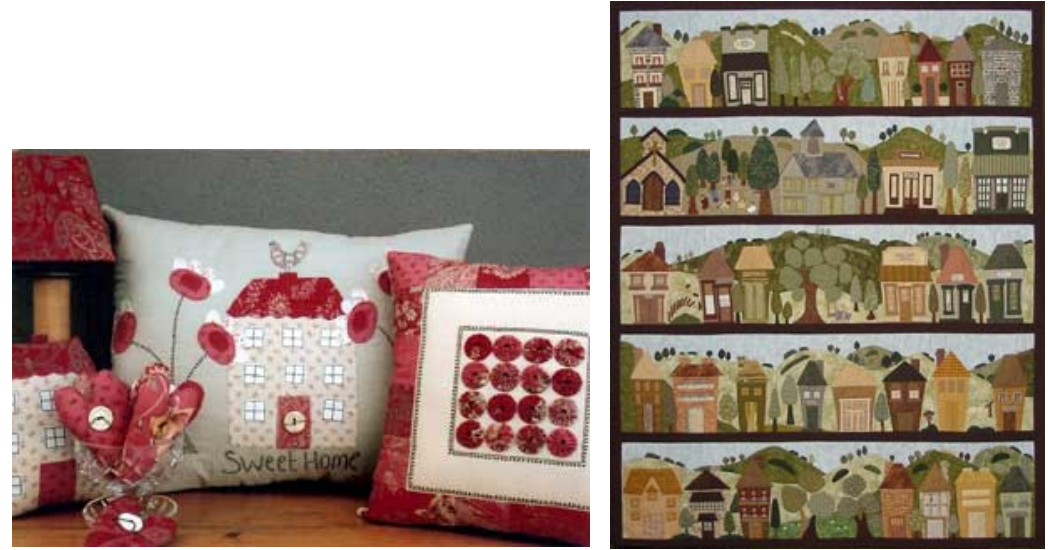

Gambar 22 Penerapan Konsep Warna Ints, Shade dan Tones pada Aksesoris Interior: Sarung Bantal, Tempat Tissue dan Wall Hanging

Dengan memiliki pengetahuan dasar kombinasi warna yang baik, maka hasil suatu desain aplikasi terutama yang berkaitan dengan produk aksesoris penunjang interior, akan terlihat lebih harmonis, menarik, indah dipandang dan dapat mendukung image atau style yang diinginkan, seperti ceria, elegan, feminin, relaks, romantis, maskulin dan lain-lain yang dapat mendukung image ruang disekitarnya.

\section{Pengembangan Rangkaian Koleksi Desain}

Rangkaian koleksi desain dalam menjahit aplikasi kain perca secara umum dapat dikembangkan secara melebar/horisontal, yaitu produk diperluas sehingga terdiri dari berbagai jenis kategori. Seiring dengan meningkatnya permintaan akan produk ini dengan beragam jenis dan kategori, maka pengrajin atau wirausahawan industri rumah tangga yang semula hanya bergerak di bidang pakaian, mulai menambah produksinya di bidang barang souvenir, perlengkapan masak, interior, kantor, dan lain-lain. Sedangkan bila secara vertikal/kedalaman, maka setiap kategori produk 
akan memiliki berbagai jenis produk yang saling mendukung. Pengrajin atau wirausahawan yang awalnya hanya memproduksi dua jenis barang di satu kategori akan memperbanyak varisi produknya. Sebagai contoh : barang di kategori aksesoris interior yang semula hanya sprei dan sarung bantal mengalami penambahan rangkaian produk lainnya, seperti kap lampu, bantal kursi, penutup meja, tempat tissue, alas piring, tempat majalah, hiasan dinding dan lain-lain. Di bawah ini adalah contoh rangkaian koleksi produk aplikasi kain perca penunjang perlengkapan interior.

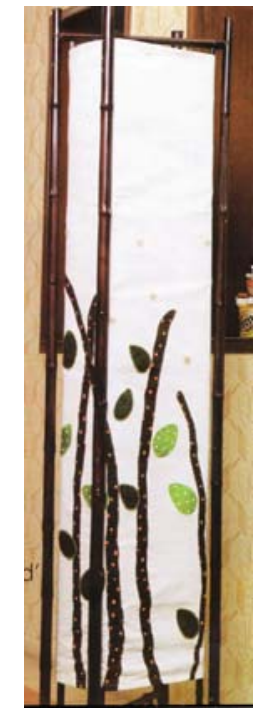

Standing Lamp

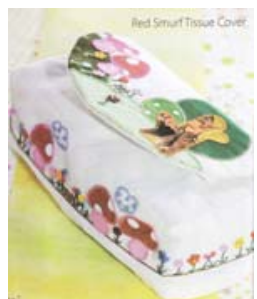

Tempat tissue

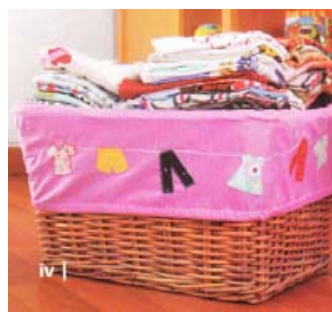

Penutup boks pakaian

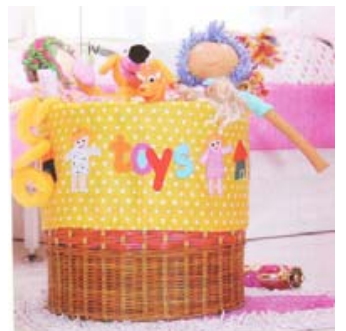

Penutup boks mainan
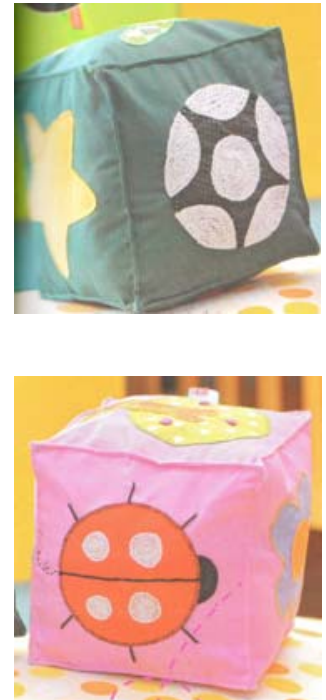

Puff/Stool/Bean bag

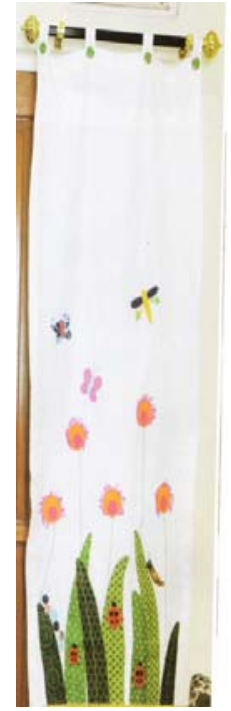

Tirai

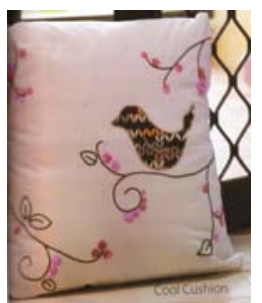

Bantal kursi

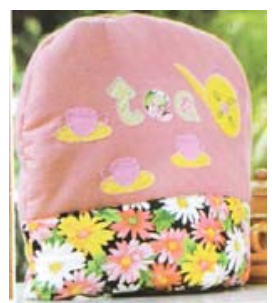

Tutup Teko

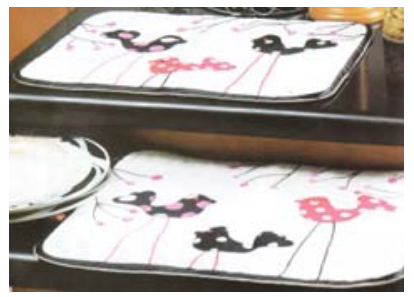

Alas piring

Di kategori perlengkapan sekolah dan kantor dari yang hanya memiliki produk cover buku, diperluas lagi hingga produk tas sekolah, penutup tas troli, tempat makan siang, tas laptop dan perlengkapan lainnya. Di bawah ini adalah contoh rangkaian koleksi produk aplikasi kain perca penunjang perlengkapan sekolah dan kantor.

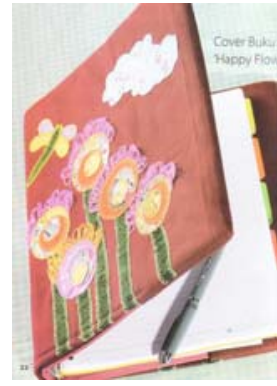

Penutup buku

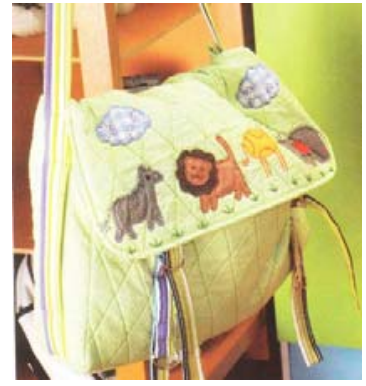

Tas pundak

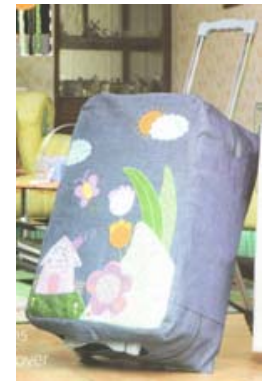

Tas Troli 


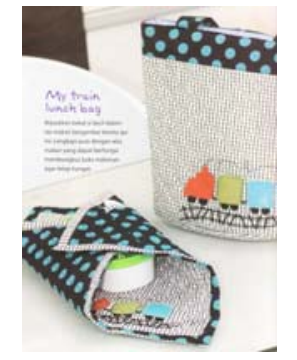

Tas makan siang (lunch bag)

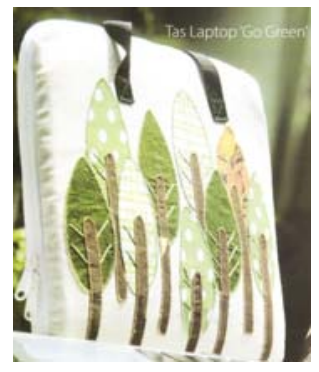

Tas Laptop

Sedangkan untuk kategori pakaian yang semula hanya kaos wanita dewasa, anak-anak dan bayi, ditambah dengan perlengkapan lainnya seperti tas, celemek (apron), bando, alas main, dan lainlain. Di bawah ini adalah rangkaian koleksi produk aplikasi untuk pakaian dan perlengkapannya.

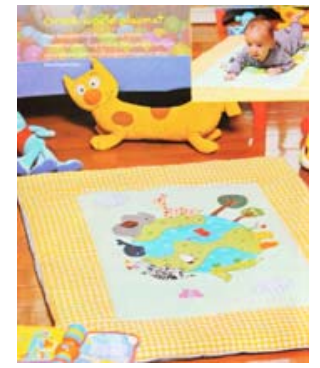

Alas main

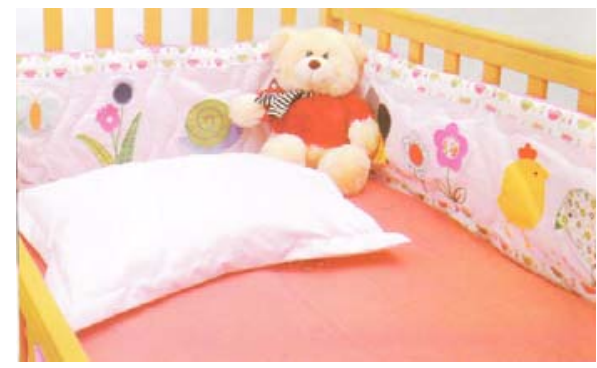

Penutup boks bayi (baby bumper)

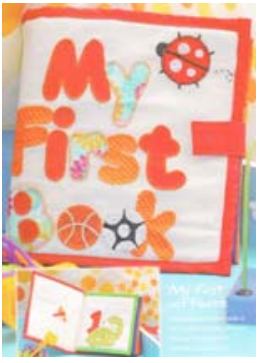

Story Book

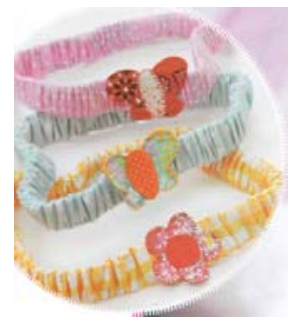

Bando

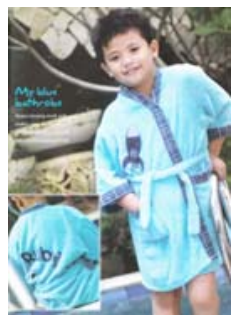

Baju handuk

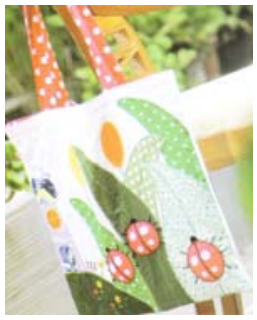

Tas

Produk : Caremommies Design

\section{SIMPULAN}

Proses pengembangan desain yang meliputi pengembangan inspirasi desain, pengetahuan akan komposisi, proporsi, bentuk, warna dan rangkaian koleksi desain akan sangat membantu keberlanjutan industri rumah tangga di bidang seni menjahit aplikasi kain perca ini. Dengan pengetahuan akan pengembangan desain, pengrajin atau wirausahawan selain dapat lebih kreatif dan inovatif dalam menghasilkan desain baru juga dapat secara mandiri berupaya menemukan identitas dan karakteristik produknya. Sedangkan melalui pengembangan rangkaian koleksi desain, permintaan pasar yang beragam dapat pula terserap dan menambah omset penjualan disaat produk utama mengalamai penurunan permintaan pasar. 
Kajian dalam tulisan ini akan diperluas lagi mengingat secara keseluruhan, keberhasilan dan keberlanjutan dari industri ini akan dipengaruhi pula oleh pengetahuan akan pentingnya kuantitas dan kualitas produk, biaya produksi, merk/brand, penetapan harga, kemasan/packaging, saluran distribusi, marketing, promosi dan pengelolaan harian dari proses manajemen produksi. Apabila semua aspek tersebut di atas sudah lebih dipahami maka industri rumah tangga ini diharapkan dapat lebih kreatif, inovatif, bertahan menjadi suatu industri yang ramah lingkungan dan tanpa limbah (zero waste industry) bahkan mampu mengembangkan bisnisnya dengan memiliki pula pengetahuan tentang pengembangan bisnis di masa depan.

Prospek kajian ini sangat sarat dengan kerjasama multi disiplin ilmu. Hal mendesak yang diperlukan saat ini adalah adanya panduan menyeluruh berbentuk buku, audio visual, multi media, program /software komputer sederhana perihal pengetahuan tersebut di atas yang mudah dijadikan panduan dan diterapkan secara mandiri baik perorangan maupun berkelompok dalam suatu workshop. Dari segi metode menjahit, diperlukan pula suatu teknik yang lebih efektif namun tetap sederhana baik menjahit dengan tangan maupun menggunakan mesin. Diharapkan teknik yang lebih maju ini akan membuat kuantitas produksi meningkat namun dengan kualitas yang tetap terjaga disertai penyerapan tenaga kerja yang tinggi.

Akhir kata, panduan menyeluruh tersebut direncanakan dapat dijadikan model bagi pengajaran pengetahuan dasar, percepatan kreatifitas dan inovasi, pengembangan serta keberlanjutan industri seni dan kerajinan serta industri kreatif rumah tangga lainnya dari industri mikro menjadi industri makro yang berkelanjutan.

\section{DAFTAR PUSTAKA}

Adair, J. (2008). The Art of Creative Thinking. Yogyakarta: Golden Books.

Ananta, H., \& Sutjihati, E. (2009). Kreasi Trendy Sulam Perca. Jakarta: Karya Pustaka, Group Puspa Swara.

Ananta, H., \& Sutjihati, E. (2010). Sulam Perca- Unik dan Cantik. Jakarta: Karya Pustaka, Group Puspa Swara.

Business Information Focus. (2004). Profil Usaha Kecil dan Menengah di Indonesia. Tangerang: PT Bisinfocus Data Pratama.

John, J. C. (1992). Design Methods (1897-1990). London: David Fulton Publisher.

Kementerian Koperasi dan UKM. (2006). Buku Proceeding Bursa Kemitraan Workshop dan Temu Bisnis. Jakarta: Deputi Bidang Pemasaran dan Jaringan Usaha- Kementerian Koperasi dan UKM.

Roesli, R., \& Art Book Team. (2009). Seni Menjahit Aplikasi. Jakarta: Gramata Publishing.

Tiger Media, (2000-2010). Color Harmony, Basic color - Basic techniques for combining colors, dari www.tigercolor.com.

Wong, W. (1972). Beberapa asas merancang dua dwimatra. Bandung: Van Nostrand Reinhold Coma. 


\section{RIWAYAT PENULIS}

Titi Indahyani lahir di kota Yogyakarta pada 9 Oktober 1968. Penulis menamatkan pendidikan S1 di Universitas Trisakti dalam bidang Interior pada 1993, meneruskan di Program Diploma di International Correspondence Singapore dalam bidang Interior Design/Decorator pada 1998 dan masih menempuh pendidikan S2 di Universitas Terbuka dalam bidang Marketing Management. Saat ini bekerja sebagai Subject Content Coordinator merangkap PIC Research di Universitas Bina Nusantara. Penulis aktif di Himpunan Desainer Interior Indonesia (HDII) sebagai anggota Profesional dan sudah menulis buku dengan judul "Seni Menjahit Aplikasi” yang diterbitkan oleh Gramata Publishing pada 2009. 